\title{
Rapport sur la rencontre annuelle de la section québécoise de l'Association canadienne des bibliothèques, archives et centres de documentation musicaux (SQACBM)
}

\author{
22 octobre 2021 (en ligne) \\ Texte rédigé par le C.A. 2020-2021 de la SQACBM: \\ - Rachel Gagnon, Présidente \\ - Julie Carmen Lefebvre, Vice-présidente \\ - Christiane Melançon, Trésorière \\ - Catherine Jolicoeur, Agente de communication
}

La section québécoise de l'Association canadienne des bibliothèques, archives et centres de documentation musicaux (SQACBM) a tenu sa rencontre annuelle le vendredi 22 octobre 2021. La rencontre s'est déroulée en ligne et a réuni une quarantaine de participant.es. Après le discours d'ouverture de la présidente sortante Rachel Gagnon et les salutations de la présidente actuelle de I'ACBM Maureen Nevins, la journée fut entamée en compagnie de Houman Behzadi qui nous présenta les fruits d'un long travail: les orientations stratégiques de l'ACBM (mai 2021). Le document vise la reconnaissance de l'ACBM en tant qu'association viable, la valorisation du travail de ses membres et sa contribution au patrimoine musical canadien. Rachel Gagnon nous a par la suite partagé ses Coups de cœur de la Conférence de l'ACBM qui s'est tenue en juin 2021 et nous invite à participer à la prochaine édition de la conférence de l'ACBM prévue en 2022!

La présentation suivante portait sur le Centre de musique canadienne (CMC) au Québec. Sa directrice générale et artistique Claire Marchand, de même que le spécialiste en sciences de l'information Louis-Noël Fontaine, nous ont présenté un survol des services, de la bibliothèque et des archives du CMC. De plus, ils nous ont présenté leurs tout nouveaux catalogues d'œuvres pour chœur (octobre 2021) ${ }^{1}$ ainsi que le catalogue d'œuvres pour orchestre (mars 2021). ${ }^{2}$

Oscar Salazar Varela a ensuite débuté la période consacrée aux conférences éclair en nous faisant découvrir le nouveau Pavillon, espace musical de BAnQ $!^{3}$ Conçu comme un lieu d'expérimentation et d'apprentissage de la musique, il est accessible en tout temps aux usagers de la Grande Bibliothèque. Après, Catherine Jolicoeur nous a partagé : « La bonification du site web du Conservatoire ou comment profiter d'une pandémie! » Au printemps 2020, l'équipe s'est retrouvée en télétravail et en a profité pour augmenter substantiellement le contenu de la section Ressources

\footnotetext{
${ }^{1}$ Pour accéder au catalogue : https://cmcquebec.files.wordpress.com/2021/10/catalogue-choeur-completoctobre-2021-web-1.pdf.

${ }^{2}$ Pour accéder au catalogue : https://cmcquebec.files.wordpress.com/2021/03/catalogue-mars-2021-web.pdf.

${ }^{3}$ Pour accéder au site : https://guides.banq.qc.ca/pavillon.
} 
du site web par l'ajout de guides par instrument et d'une section sur ses donateurs. ${ }^{4}$ Et puis, s'est enchaîné « Le guide sujet à la Bibliothèque de musique Marvin Duchow de l'Université McGill: un outil évolutif » par Melissa Pipe. Cette présentation portait sur la nouvelle itération du guide sujet Jazz de la Bibliothèque de musique Marvin Duchow. ${ }^{5}$ Retravaillé au cours des derniers mois, ce guide témoigne des efforts que mène la bibliothèque à enrichir ses guides existants et à en créer de nouveaux pour mieux répondre aux besoins de ses usagers dont les guides LGBTQ+ et Women composers. ${ }^{6}$ Trevor Deck (Université de Toronto) et Mélissa Gravel (Université Laval) nous ont par la suite partagé leurs réalités et "Expériences d'utilisation de nkoda en bibliothèques universitaires ". Leurs témoignages ont soulevé beaucoup de questions et de commentaires: un sujet d'actualité qui ne laisse personne indifférent.

Lors de l'assemblée générale, des élections ont eu lieu afin de remplacer Rachel Gagnon et Christiane Melançon dont les mandats se terminaient. Les personnes élues pour les remplacer sont Frédéric Tremblay de l'Université de Montréal et Marie Ève Cossette du Cégep de Saint-Laurent. De chaleureux remerciements ont été adressés à Rachel Gagnon et Christiane Melançon pour leur dévouement, leur implication et leur engagement depuis de nombreuses années dans cette communauté passionnée de musique!

\title{
Report on the Quebec chapter of CAML (Canadian Association of Music Libraries, Archives and Documentation Centers)
}

\author{
October 22, 2021 (online) \\ Report prepared by the Board of Directors 2020-2021 of the Québec Chapter of ACBM: \\ - Rachel Gagnon, President \\ - Julie Carmen Lefebvre, Vice President \\ - Christiane Melançon, Treasurer \\ - Catherine Jolicoeur, Communications Officer
}

The Quebec chapter of the Canadian Association of Music Libraries, Archives and Documentation Centers (SQACBM) held its annual meeting on Friday, October 22, 2021. The meeting took place online and brought together roughly forty participants. After the welcoming speech by Rachel Gagnon, our outgoing president, and the warm greetings from the current president of CAML,

\footnotetext{
${ }^{4}$ Accédez à la section Ressources (https://biblio.cmadq.gouv.qc.ca/ressources) ainsi que les guides numériques (https://biblio.cmadq.gouv.qc.ca/) sur le site web du Conservatoire de musique et d'art dramatique du Québec.

${ }^{5}$ Visitez le guide sujet Jazz de la Bibliothèque de musique Marvin Duchow : https://libraryguides.mcgill.ca/iazzguide.

${ }^{6}$ Visitez les guides sujets LGBTQ+ (https://libraryguides.mcgill.ca/lgbtqmusic) et Women Composers (https://libraryguides.mcgill.ca/womencomposers) de la Bibliothèque de musique Marvin Duchow.
} 
Maureen Nevins, our day started off in the company of Houman Behzadi who presented us with the outcome of CAML's recent work: their newly created Strategic Directions (May 2021). Following Houman's presentation, Rachel Gagnon shared her favourite moments from the CAML conference held in June 2021 and encouraged participants to attend the next edition of the CAML conference scheduled for 2022.

The next presenter focused on the Canadian Music Center (CMC) in Quebec. Claire Marchand, general and artistic director of the CMC and Louis-Noël Fontaine, specialist in information sciences, gave us an overview of the CMC's services, library, and archives. In addition, they proudly introduced their brand-new catalogs of choral works ${ }^{1}$ (October 2021) as well as the catalog of works for orchestra (March 2021). ${ }^{2}$

Next, Oscar Salazar Varela began the period dedicated to the "flash conferences" by introducing us to the new Pavillon, espace musical de BAnQ! ${ }^{3}$ Designed as a unique place to experiment and learn music, it is always accessible to users of the Grande Bibliothèque. Following this, Catherine Jolicoeur shared with us her presentation titled "Improving the Conservatory's website, or how to take advantage of a pandemic!" In the spring of 2020, the library team found itself working remotely. They took advantage of this opportunity to substantially increase the content of the Resources section of their website by adding subject guides for instruments and a dedicated section to honor their donors. ${ }^{4}$ This led the way to the next presentation on subject guides at McGill University's Marvin Duchow Music Library by Melissa Pipe. This presentation focused on the new iteration of the Jazz subject guide. ${ }^{5}$ Recently redesigned, this guide reflects the efforts of the library to enrich its existing guides and create new ones to better meet the needs of its users. Other newly created guides such as the LGBTQ+ and Women composers guides were also featured. ${ }^{6}$ Trevor Deck (University of Toronto) and Mélissa Gravel (Université Laval) then shared with us their realities and experiences on using nkoda in their respective music libraries. Their testimonies raised many questions and comments: a topic that leaves no one indifferent.

Before bringing the meeting to an end, elections were held at our general assembly to replace Rachel Gagnon and Christiane Melançon whose terms were coming to an end. As a result of this, we are pleased to welcome Frédéric Tremblay from Université de Montréal and Marie Ève Cossette

\footnotetext{
${ }^{1}$ View the catalogue of choral works: https://cmcquebec.files.wordpress.com/2021/10/catalogue-choeurcomplet-octobre-2021-web-1.pdf.

${ }^{2}$ View the catalogue of works for orchestra: https://cmcquebec.files.wordpress.com/2021/03/catalogue-mars2021-web.pdf.

${ }^{3}$ Visit the website of Le Pavillon, espace musical of the BAnQ: https://guides.banq.qc.ca/pavillon.

${ }^{4}$ Visit the Resources (https://biblio.cmadq.gouv.qc.ca/) section of the website of the Conservatoire de musique et d'art dramatique du Québec, and their subject guides (https://biblio.cmadq.gouv.qc.ca/).

${ }^{5}$ View the Marvin Duchow Music Library's Jazz subject guide: https://libraryguides.mcgill.ca/jazzguide.

${ }^{6}$ View the Marvin Duchow Music Library's LGBTQ+ (https://libraryguides.mcgill.ca/lgbtqmusic) and Women Composers (https://libraryguides.mcgill.ca/womencomposers) subject guides.
} 
from Cégep de Saint-Laurent to the Board of Directors! Heartfelt thanks were expressed to Rachel Gagnon and Christiane Melançon for their dedication and commitment of many years in this passionate music community! 